\title{
KESULITAN MAHASISWA CALON GURU FISIKA DALAM MEREPRESENTASIKAN KONSEP LISTRIK MAGNET
}

\author{
W Handayani, ${ }^{1,4}$,W Setiawan",2 P Sinaga1,3, dan A. Suhandi, ${ }^{1,3}$ \\ ${ }^{1}$ Sekolah Pascasarjana, Universitas Pendidikan Indonesia, Jl. Dr. Setiabudi No 229, Bandung, \\ Indonesia \\ ${ }^{2}$ Departemen Pendidikan Ilmu Komputer, Universitas Pendidikan Indonesia, Jl. Dr. Setiabudi No \\ 229, Bandung, Indonesia \\ ${ }^{3}$ Departemen Pendidikan Fisika, Universitas Pendidikan Indonesia, Jl. Dr. Setiabudi No 229, \\ Bandung, Indonesia \\ ${ }^{4}$ Program Studi Pendidikan Fisika Fakultas Tarbiyah dan Keguruan UIN Sunan Gunung Djati \\ Bandung Jl. A H. Nasution No 105 Bandung
}

E-mail: wahyuni_han@student.upi.edu

\begin{abstract}
ABSTRAK
Komunikasi dalam sains bersifat multimodus (verbal dan visual). Keterampilan representasi adalah salah satu keterampilan komunikasi dalam sains. Seorang guru fisika dituntut untuk memiliki keterampilan representasi agar saat pelaksanaan pembelajaran di kelas, siswa dapat lebih mudah mengakses konsep fisika yang dipelajarinya dan gurupun lebih mudah mengomunikasikan konsep-kosep fisika kepada siswanya. Studi ini meneliti keterampilan representasi mahasiswa calon guru fisika. Terdapat tiga aspek keterampilan representasi, yaitu 1) keterampilan membuat representasi modus tunggal, 2) keterampilan translasi antar modus representasi dan 3) keterampilan multi representasi. Instrumen yang digunakan untuk mengukur keterampilan representasi telah divalidasi dan digunakan untuk mengukur keterampilan representasi mahasiswa calon guru fisika pada materi listrik magnet. Hasil penelitian menunjukkan bahwa mahasiswa mengalami kesulitan pada seluruh aspek keterampilan representasi. Hal ini dikarenakan belum pernah ada pembelajaran terkait keterampilan representasi maupun asesmen yang khusus menguji keterampilan representasi mereka.
\end{abstract}

Kata kunci: representasi, representasi modus tunggal, translasi antar modus representasi, multi representasi

\section{ABSTRACT}

Communication in science is multimodal (verbal and visual). Representation skills are one of the communication skills in science. A physics teacher is required to have representation skills so that the students more easily to acsess the concept that they have to lean and the teacher communicate physics concepts more easily to his students. This study examines the representation skills of preservice physics teacher. Three aspects of representation skills, that examined are: 1) the skill of making a single mode representation, 2) the skills of translation between representation modes and 3) multi-representation skills. The instrument used to measure representation skills has been validated and used to measure representation skills of preservice physics teacher in Listrik-Magnet courses. The results showed that the preservive physics student have difficulty in making all of the aspect of representation. It is occured because there has never been learning related to representation or assessment skills that specifically test their representation skills

Keywords: representation, single modes representation, translation among modes of representation, multiplerepresentation

DOI: http://dx.doi.org/10.15575/jtlp.v2i2.6581

Received: 20 Juli 2017 ; Accepted: 20 Agustus 2017 ; Published: 1 September 2017 


\section{PENDAHULUAN}

Representasi adalah suatu konfigurasi (bentuk atau susunan) yang dapat menggambarkan, mewakili atau melambangkan sesuatu dalam suatu cara (Goldin, 2002). Keterampilan representasi merupakan bagian dari keterampilan komunikasi dalam sains, sebagaimana dinyatakan oleh Scherz, SpektorLevy \& Eylon (Spektor-Levy, 2008), keterampilan komunikasi sains memiliki fokus utama pada keterampilan temu kembali informasi (information retrieval), membaca sains (scientific reading), mendengarkan dan mengamati (listening and observing), menulis sains (scientific writing), merepresentasi informasi (information representation), dan menyajikan pengetahuan (knowledge presentation). Dalam pengajaran sains, untuk membentuk esensi makna ilmiah, bahasa yang digunakan oleh guru harus mencakup kalimat, gestur, dan gambar yang secara kooperatif mengekspresikan gagasan yang sama dan gurupun harus mampu mengaitkan makna sebuah konsep atau fenomena yang menjalankan fungsi yang berbeda dengan dua representasi bahasa atau lebih (Kress, 2001). Sains tidak dibuat atau dikomunikasikan sematamata melalui bahasa lisan atau tulisan. Menurut Lemke (Lemke, 1999) bahasa sains bersifat hibrid semiotik yang mengandung komponen verbal (tipologis) dan matematis, visual-grafis, dan aksi operasional (topologis). Karena materi subjek sains jauh berbeda dengan matematika, bahasa, sejarah dll, maka seorang guru sains perlu memiliki keterampilan mengajar yang berbeda dalam mengajar subjek yang berbeda (Das, 2014). Teori beban kognitif menyatakan bahwa kemampuan pemrosesan manusia sangat terbatas. Namun, teori dual-processing berpendapat bahwa otak manusia memiliki sistem pemrosesan yang terpisah untuk input visual dan verbal yang dapat digunakan secara bersamaan. Gagasan dual-processing mengusulkan efek multimedia yaitu, siswa mampu belajar lebih baik menggunakan katakata dan gambar daripada dari kata-kata saja. Dengan demikian, mengingat kapasitas pemrosesan otak yang terbatas dan peluang untuk meningkatkan saluran pemrosesan ganda, penggunaan multirepresentasi dinilai merupakan metode yang paling efisien untuk mengkomunikasikan pesan tertentu tanpa beban kognitif (Arey, 2017)

Dalam makalah ini yang dimaksud dengan keterampilan representasi adalah keterampilan seorang guru fisika dalam menjelaskan sebuah konsep atau hukum fisika menggunakan representasi verbal (modus teks) dan visual (modus gambar, diagram, tabel, grafik dan persamaan matematika) yang terdiri dari: 1) keterampilan menjelaskan konsep/hukum fisika menggunakan modus representansi tunggal, 2) keterampilan mengubah sebuah modus representansi yang satu ke modus representasi lain atau disebut keterampilan translasi antar modus representasi dan 3) keterampilan menjelaskan konsep/hukum fisika dalam beberapa modus representasi atau disebut juga keterampilan multirepresentasi (MR). Keterampilan representasi penting dikuasai oleh guru agar ia dapat memfasilitasi siswa yang memiliki keragaman kemampuan dalam memahami konsep fisika. Memilih, mengoordinasi, dan berpindah di antara representasi adalah keterampilan penting dalam pembelajaran dan praktek fisika (Arey, 2017). Penelitian-penelitian tekait MR menunjukkan dua kelebihan penting dari penggunaan multirepresentasi yaitu: 1) MR memberi kesempatan yang luas pada guru untuk melayani siswa yang gaya belajarnya berbeda-beda sehingga meningkatkan pembelajaran yang efektif (Mallet, 2007) dan 2) penggunaan MR menghantarkan siswa pada pemahaman yang mendalam pada mata pelajaran karena setiap representasi menekankan pada aspek yang berbeda untuk konsep yang sama (Kohl, 2017)

Keterampilan representasi konsep merupakan kompetensi ilmiah yang harus dikuasai oleh guru dengan baik. Mengingat pentingnya keterampilan representasi, maka calon guru harus dibekali dengan keterampilan tersebut sejak masih menjadi mahasiswa calon guru. Program penyiapan calon guru harus mampu menghasilkan calon guru yang memiliki kompetensi setinggi mungkin (Berthold, 2009). 
Keterampilan representasi diperlukan untuk pengembangan kompetensi profesional secara mandiri dan berkelanjutan terutama saat guru menggunakan keterampilan tersebut untuk berkomunikasi dengan siswa baik secara lisan yaitu dalam wacana di kelas maupun secara tertulis dalam bentuk materi ajar yang ditulis oleh guru. Para peneliti telah sepakat bahwa guru profesional seharusnya tidak hanya menguasai pengetahuan yang dalam tentang konsep dan prosedur tetapi ia juga harus paham cara mengajarkan konsep, yang disebut pengetahuan konten-pedagogik. Seperti pernyataan Shulman (Shulman, 1986) dan Grossman (Grossman, 1990) memahami dan menggunakan representasi adalah aspek utama dalam pengetahuan konten-pedagogi.

\section{METODE PENELITIAN}

Keterampilan representasi dalam penelitian ini adalah studi pendahuluan yang merupakan studi awal dari rangkaian aktivitas penelitian keterampilan komunikasi sains pada mahasiswa calon guru fisika. Metoda penelitian adalah deskriptif-kuantitatif. Partisipan dalam penelitian ini adalah mahasiswa calon guru fisika semster VI yang berjumlah 20 orang yang dipilih secara acak. Konten materi yang digunakan untuk mengetahui keterampilan representasi mahasiswa adalah Listrik-Magnet yang pada umumnya di perguruan tinggi diajarkan dalam mata kuliah Fisika Dasar II. Dengan demikian materi tersebut telah dipelajari oleh mahasiswa tersebut. Bahkan semua mahasiswa semester 6 yang terlibat dalam penelitian ini telah mengambil matakuliah Listrik-Magnet. Pengambilan data dilakukan pada semester genap pekan ke 12. Instrumen tes keterampilan representasi yang digunakan dalam penelitian ini, terdiri dari 3 butir soal keterampilan representasi berbentuk uraian terbatas yang diambil dari instrumen tes keterampilan representasi yang dikembangkan oleh Sinaga (Sinaga, 2014). Instrumen tes keterampilan representasi diperlihatkan pada Gambar 1.

Jawaban mahasiswa dianalisis menggunakan rubrik yang dikembangkan untuk menganalisis keterampilan representasi materi listrik-magnet. Rincian rubrik untuk setiap butir soal telah diupayakan dapat membedakan variasi dan menilai setiap jawaban mahasiswa dengan cara mengikuti standar normatif dengan merujuk sumber-sumber referensi. Skor maksimum ditetapkan 100 yang terdiri dari: 1) skor maksimum keterampilan menjelaskan konsep/hukum fisika menggunakan modus representansi tunggal sebesar 50, 2) translasi antar modus representasi sebesar 40 dan 3) menjelaskan konsep/hukum fisika dalam multi representasi sebesar 10 .

1. Buatlah penjelasan hukum Coulomb menggunakan

a. Representasi teks

b. Representasi diagram piktorial

c. Representasi tabel

d. Representasi grafik

e. Representasi persamaan matematik

2. Translasi antar modus representasi.

Penghantar lurus panjang yang dialiri arus listrik ditempatkan pada sebuah magnet, maka pada penghantar ini akan bekerja gaya. Besar gayanya berbanding lurus dengan arus yang mengalir pada penghantar, berbanding lurus dengan besar medan magnet dan dengan sinus sudut yang dibentuk oleh arah arus dan arah medan magnet. Gaya yang bekerja pada penghantar akan maksimum ketika arah arus tegak lurus terhadap arah medan magnetnya. Arah gaya yang bekerja pada penghantar ialah tegak lurus terhadap bidang yang dibentuk oleh arus dan arah medan magnet. Arah gaya yang bekerja pada penghantar juga dapat ditentukan dengan menggunakan kaidah tangan kanan dimana arah ibu jari menyatakan arah arus listrik, arah keempat jari lainnya menyatakan arah medan magnet dan arah terbukanya telapak tangan menyatakan arah gaya.

Buatlah penjelasan gaya penghantar berarus yang diuraikan dalam representasi teks tersebut ke dalam:

a. Representasi diagram piktorial

b. Representasi persamaan matematika

3. Representasi persamaan matematika dari konsep gaya magnet pada muatan listrik ialah $\mathrm{F}=\mathrm{qV} \times \mathrm{B}$ atau dapat pula dinyatakan dalam persamaan $\mathrm{F}=\mathrm{qVB}$ $\sin \theta$, dengan $\theta$ adalah sudut yang dibentuk oleh $V$ dan $B, q$ adalah muatan listrik serta $B$ adalah kuat medan magnet.

Buatlah penjelasan konsep tersebut menggunakan:

a. Representasi teks

b. Representasi gambar 
Gambar 1. Instrumen Tes Keterampilan Representasi

Butir-butir soal terdiri dari: 1) keterampilan menjelaskan konsep/hukum fisika menggunakan modus representansi tunggal sebanyak 5 butir, 2) translasi antar modus representasi sebanyak 4 butir dan 3) menjelaskan konsep/hukum fisika dalam multi representasi sebanyak 1 butir. Keterampilan menjelaskan konsep/hukum fisika dalam multi representasi dianalisis dari soal RUBRIK PENILAIAN KETERAMPILAN REPRESENTASI

\begin{tabular}{|c|c|c|c|c|c|c|}
\hline \multirow[b]{2}{*}{$\begin{array}{l}\text { No. } \\
\text { Soal }\end{array}$} & \multirow{2}{*}{$\begin{array}{c}\text { Indikator Keterampilan } \\
\text { Representasi }\end{array}$} & \multicolumn{5}{|c|}{ Skor Keterampilan } \\
\hline & & 0 & 1 & 2 & 3 & 4 \\
\hline $1 . \mathrm{a}$ & $\begin{array}{l}\text { Mampu menjelaskan hukum } \\
\text { Coulomb dalam representasi teks }\end{array}$ & $\begin{array}{l}\text { Tidak ada } \\
\text { representasi } \\
\text { teks hukum } \\
\text { Coulomb }\end{array}$ & $\begin{array}{l}\text { Representasi teks tidak } \\
\text { sesuai kaidah ilmiah } \\
\text { hukum Coulomb dan } \\
\text { tidak disertai dengan } \\
\text { narasi penjelas }\end{array}$ & $\begin{array}{l}\text { Representasi teks benar dan } \\
\text { sesuai dengan kaidah ilmiah } \\
\text { hukum Coulomb namun } \\
\text { tidak disertai dengan narasi } \\
\text { penjelas }\end{array}$ & $\begin{array}{l}\text { Representasi teks benar, } \\
\text { sesuai dengan kaidah } \\
\text { ilmiah hukum Coulomb } \\
\text { dan disertai dengan sedikit } \\
\text { narasi penjelas }\end{array}$ & $\begin{array}{l}\text { Representasi teks benar, sesuai } \\
\text { dengan kaidah ilmiah hukum } \\
\text { Coulomb dan disertai dengan } \\
\text { narasi penjelas }\end{array}$ \\
\hline $1 . \mathrm{b}$ & 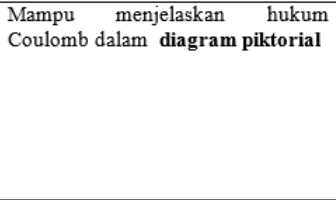 & $\begin{array}{l}\text { Tidak ada } \\
\text { diagram } \\
\text { piktorial } \\
\text { hukum } \\
\text { Coulomb }\end{array}$ & $\begin{array}{l}\text { Diagram piktorial tidak } \\
\text { memenuhi kaidah ilmiah } \\
\text { Representasi diagram } \\
\text { piktorial hukum Coulomb }\end{array}$ & $\begin{array}{l}\text { Diagram piktorial memenuhi } \\
\text { kaidah ilmiah Representasi } \\
\text { diagram piktorial hukum } \\
\text { Coulomb tapi masih ada } \\
\text { kesalahan }\end{array}$ & $\begin{array}{l}\text { Diagram piktorial Benar } \\
\text { dan memenuhi kaidah } \\
\text { ilmiah Representasi } \\
\text { diagram piktorial tapi } \\
\text { simbol-simbol muatan, } \\
\text { jarak dan gaya tdak } \\
\text { semuanya ditampilkan }\end{array}$ & $\begin{array}{l}\text { Diagram piktorial Benar dan } \\
\text { memenuhi kaidah ilmiah } \\
\text { Representasi diagram piktorial } \\
\text { dan lengkap dengan simbol- } \\
\text { simbol muatan, jarak dan gaya }\end{array}$ \\
\hline $1 . \mathrm{c}$ & $\begin{array}{l}\text { Mampu menjelaskan hukum } \\
\text { Coulomb dalam representasi tabel }\end{array}$ & Tidak ada tabel & $\begin{array}{l}\text { Representasi tabel tidak } \\
\text { memenuhi kaidah ilmiah } \\
\text { Representasi tabel atau } \\
\text { representasi tabel salah }\end{array}$ & $\begin{array}{l}\text { Representasi tabel Kurang } \\
\text { memenuhi kaidah ilmiah } \\
\text { Representasi tabel (ada judul } \\
\text { kolom tapi tidak melengkapi } \\
\text { dengan satuannya) dan tidak } \\
\text { menampilkan seluruh besaran } \\
\text { yang terdapat dalam } \\
\text { persamaan Coulomb }\end{array}$ & $\begin{array}{|lr|}\text { Representasi } & \text { tabel } \\
\text { memenuhi kaidah } & \text { ilmiah } \\
\text { Representasi tabel } & \text { (ada } \\
\text { judul kolom dan ada satuan) } \\
\text { meskipun } & \text { tidak } \\
\text { menampilkan } & \text { seluruh } \\
\text { besaran yang terdapat dalam } \\
\text { persamaan Coulomb }\end{array}$ & $\begin{array}{l}\text { Representasi tabel benar dan } \\
\text { memenuhi kaidah ilmiah } \\
\text { Representasi tabel (ada judul } \\
\text { kolom dan ada satuan) dan } \\
\text { lengkap (menampilkan seluruh } \\
\text { besaran yang terdapat dalam } \\
\text { persamaan Coulomb) }\end{array}$ \\
\hline $3 . \mathrm{a}$ & $\begin{array}{l}\text { Mampu mentranslasi representasi } \\
\text { persamaan matematika ke } \\
\text { representasi teks }\end{array}$ & $\begin{array}{l}\text { Tidak ada } \\
\text { representasi } \\
\text { teks }\end{array}$ & $\begin{array}{l}\text { Representasi teks tidak } \\
\text { relevan dengan kaidah } \\
\text { ilmiah gaya Loretnz atau } \\
\text { representasi teks salah }\end{array}$ & $\begin{array}{l}\text { Representasi teks relevan } \\
\text { dengan kaidah ilmiah gaya } \\
\text { Loretnz tapi hanya } \\
\text { mengubah persamaan } \\
\text { matematika menjadi teks }\end{array}$ & $\begin{array}{l}\text { Representasi teks relevan } \\
\text { kaidah ilmiah gaya Loretnz, } \\
\text { meskipun narasinya hanya } \\
\text { mengubah peramaan } \\
\text { matematika menjadi teks }\end{array}$ & $\begin{array}{l}\text { Representasi teks relevan dengan } \\
\text { kaidah ilmiah gaya Loretnz } \\
\text { dengan narasi yang memenuhi } \\
\text { kaidah ilmiah gaya Lorentz dan } \\
\text { disertai dengan narasi penjelas }\end{array}$ \\
\hline
\end{tabular}

Gambar 2. Rubrik Penilaian Keterampilan Representasi

Pada penelitian ini setelah mahasiswa menjawab soal tes keterampilan representasi konsep listrik-magnet, kepada mereka diberikan angket terkait kesulitan yang dihadapi saat membuat representasi konsep listrik-mganet. Angket yang dikembangkan oleh (Sinaga, 2014) pertama yaitu keterampilan menjelaskan hukum Coulomb menggunakan modus representansi tunggal, dan keterampilan yang dianalisis terkait dengan keterpaduan dan keutuhannya dalam merepresentasikan hukum Coulomb. Sebagian dari rubrik penilaian keterampilan reresentasi diperlihatkan pada Gambar 2. berjumlah 9 butir pernyataan yang meminta pendapat mahasiswa terkait kesulitan yang dihadapinya. Sebagian dari butir-butir pertanyaan dalam angket diperlihatkan pada Gambar 3. 


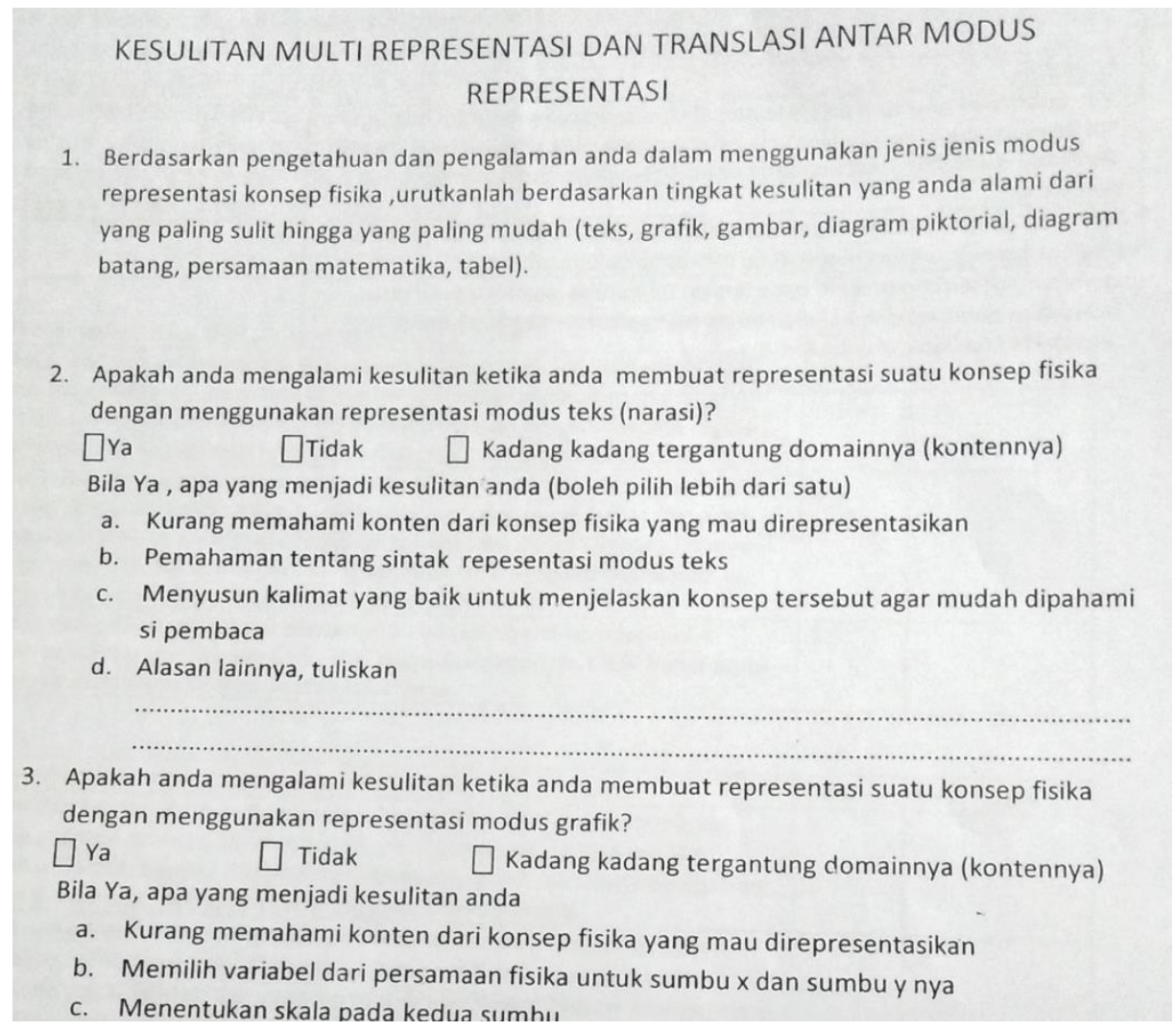

Gambar 3. Angket Kesulitan Merepresentasi Konsep Listrik-Magnet

\section{HASIL DAN PEMBAHASAN}

Keterampilan representasi yang dianalisis terdiri dari: 1) keterampilan menjelaskan konsep/hukum fisika menggunakan modus representansi tunggal, 2) keterampilan mengubah sebuah modus representansi yang satu ke modus representasi lain atau disebut keterampilan translasi antar modus representasi dan 3) keterampilan menjelaskan konsep/hukum fisika dalam beberapa modus representasi atau disebut juga keterampilan multirepresentasi.

TABEL 1. Skor rata-rata dan Simpangan Baku Keterampilan Representasi Konsep ListrikMagnet

\begin{tabular}{ccr}
\hline Indikator & $\begin{array}{c}\text { Mahasiswa Semester 6 } \\
(\mathrm{n}=20)\end{array}$ \\
\hline Skor Rata-rata & 49,5 \\
Simpangan Baku & 8,8 & \\
\hline Konten materi yang digunakan untuk & dignas \\
mengetahui & keterampilan & representasi
\end{tabular}

menggunakan modus tunggal adalah hukum Coulomb. Hukum Coulomb juga digunakan sebagai instrumen untuk mengetahui keterampilan multirepresentasi. Sedangkan konten materi yang digunakan untuk mengetahui keterampilan translasi antar modus representasi adalah konsep gaya Lorentz dan gerak partikel dalam medan magnet. Instrumen keterampilan multirepresentasi sama dengan instrumen keterampilan representasi menggunakan modus tunggal. Tetapi analisisnya menggunakan rubrik yang berbeda yaitu rubrik untuk menganalisis keterampilan multirepresentasi. Skor rata-rata dan simpangan baku dari keterampilan mahasiswa calon guru dalam merepresentasi konsep listrik-magnet diperlihatkan pada Tabel 1.

Skor rata-rata dan simpangan baku keterampilan: 1) menjelaskan konsep/hukum Coulomb dalam modus representansi tunggal, 2) translasi antar modus representasi dan 3) menjelaskan hukum Coulomb dalam multi representasi, diperlihatkan pada Tabel 2. 
Tabel 2. . Skor rata-rata dan Simpangan Baku Keterampilan Representasi untuk Setiap Komponen

\begin{tabular}{|c|c|c|c|}
\hline Aspek & Komponen Representasi & Skor Rata-rata & Simpangan Baku \\
\hline $\begin{array}{l}\text { Menjelaskan hukum Coulomb } \\
\text { dalam modus representansi } \\
\text { tunggal (Skor maksimum: } 50 \text { ) }\end{array}$ & $\begin{array}{ll}\text { a. } & \text { Teks } \\
\text { b. } & \text { Diagram piktorial } \\
\text { c. } & \text { Tabel } \\
\text { d. } & \text { Grafik } \\
\text { e. } & \text { Persamaan Matematika }\end{array}$ & $\begin{array}{l}3,8 \\
5,1 \\
5,5 \\
4,1 \\
6,0\end{array}$ & $\begin{array}{l}1,8 \\
2,7 \\
1,6 \\
1,8 \\
2,6\end{array}$ \\
\hline $\begin{array}{l}\text { Translasi antar modus } \\
\text { representasi (Skor maksimum: } \\
40 \text { ) }\end{array}$ & $\begin{array}{l}\text { a. Tanslasi dari modus } \\
\text { teks ke diagram piktorial } \\
\text { b. Translasi dari } \\
\text { modus teks ke persamaan } \\
\text { matematika } \\
\text { c.Tanslasi dari modus } \\
\text { persamaan matematika } \\
\text { ke teks } \\
\text { d. Tanslasi dari modus } \\
\quad \text { persamaan matematika } \\
\text { ke gambar }\end{array}$ & $\begin{array}{l}3,6 \\
6,5 \\
3,4 \\
3,4\end{array}$ & $\begin{array}{l}1,1 \\
1,9 \\
2,8 \\
1,8\end{array}$ \\
\hline $\begin{array}{c}\text { Menjelaskan hukum Coulomb } \\
\text { dalam multirepresentasi (Skor } \\
\text { maksimum: 10) }\end{array}$ & & 5,6 & 1,4 \\
\hline
\end{tabular}

Tabel 3 memperlihatkan tanggapan mahasiswa terkait kesulitan yang dialami dalam merepresentasikan materi pembelajaran listrikmagnet.

TABEL 3. Kesulitan Mahasiswa Terkait Representasi Konsep Listrik-Magnet

\begin{tabular}{cc}
\hline Komponen & $\begin{array}{c}\text { Kuantitas Mahasiswa } \\
\text { yang Mengalami } \\
\text { Kesulitan }\end{array}$ \\
\hline Teks & $100 \%$ \\
Gambar & $76 \%$ \\
Diagram Piktorial & $93 \%$ \\
Tabel & $87 \%$ \\
Grafik & $100 \%$ \\
Persamaan & $87 \%$ \\
Matematika & \\
\hline
\end{tabular}

\section{a. Keterampilan Menjelaskan hukum Coulomb dalam modus representansi tunggal}

Berdasarkan Tabel 2, pada aspek menjelaskan hukum Colomb dalam representasi persamaan matematika, adalah aspek yang paling unggul dibanding aspek lainnya.. Namun keteramilan membuat representasi persamaan matematika belum lengkap. Mahasiswa belum melengkapi persamaan dengan menyertakan keterangan-keterangan simbol yang terdapat dalam persamaan hukum Coulomb. Dalam menjelaskan persamaan matematika, seorang guru tidak cukup hanya menuliskan persamaan, tetapi harus disertai dengan keterangan simbol dan satuan dari setiap besaran yang terdapat di dalam persamaan. Hal ini untuk memastikan kepada siswa bahwa fisika bukanlah matematika. Setiap simbol dalam persamaan matematika memiliki arti fisis yang berkaitan dengan konsep yang sedang dipelajari.

Keterampilan menjelaskan hukum Coulomb menggunakan modus representansi teks mempunyai skor yang terendah. Sebanyak 55\% mahasiswa menjelaskan hukum Coulomb hanya dengan menyebutkan definisinya tanpa memberi penjelasan lebih lanjut atau sebaliknya, langsung memberikan penjelasan tentang hukum Coulomb tanpa menyebutkan definisinya terlebih dahulu. Sebanyak 35\% mahasiswa menyebutkan definisi hukum Coulomb tapi tidak disertasi penjelasan yang lengkap dan hanya 10\% mahasiswa menyebutkan definisinya terlebih dahulu dilanjutkan dengan menguraikan tentang 
hubungan antara jarak dengan gaya Coulomb. Contoh dari jawaban mahasiswa yang menyebutkan definisinya terlebih dahulu dilanjutkan dengan menguraikan hukum Coulomb: "Besarnya gaya interaksi antara dua muatan berbanding lurus dengan perkalian kedua muatan dan berbading terbalik dengan kuadrat jarak anatara kedua muatan. Besarnya gaya Coulomb dipengaruhi oleh jarak antara kedua muatan. Semakin jauh jarak kedua muatan maka gaya Coulomb akan semakin kecil dan sebaliknya semakin dekat jarak kedua muatan maka gaya Coulomb akan semakin besar".

\section{b. Keterampilan Translasi antar modus representasi}

Skor yang cukup tinggi ada keterampilan translasi antar modus representasi, terdapat pada aspek translasi dari modus representasi teks ke persamaan matematika. Sebanyak 45\% mahasiswa menuliskan persamaan matematika secara baku namun tanpa melengkapinya dengan keterangan dari simbol-simbol yang digunakan dari uraian tentang gaya pada penghantar lurus panjang yang dialiri arus listrik yang ditempatkan pada sebuah magnet. Ada sebanyak 35\% mahasiswa menuliskan persamaan matematika tidak baku dan tanpa melengkapinya dengan keterangan dari simbol-simbol yang digunakan. Sisanya, 20\% mahasiswa menuliskan persamaan matematika secara baku dan melengkapinya dengan keterangan dari simbol-simbol yang digunakan dalam persamaan matematika tersebut, seperti tampak pada Gambar 3.

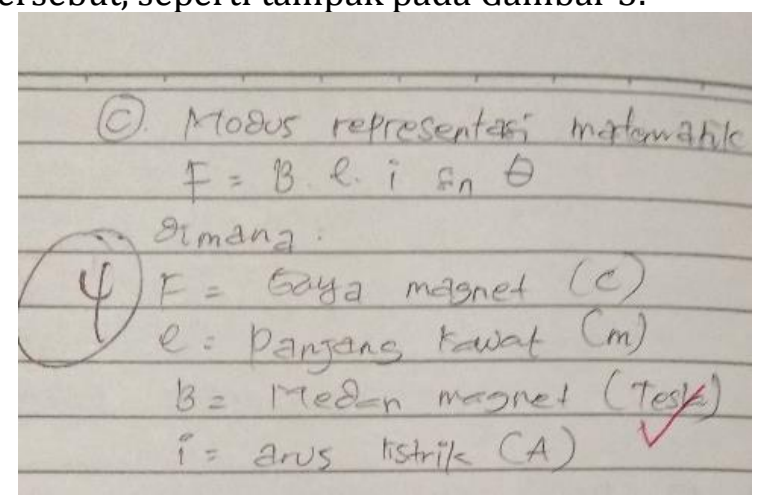

Gambar3. Representasi Persamaan Matematika dari Konsep Gaya pada Penghantar Lurus Panjang
Skor terendah terdapat pada keterampilan translasi dari modus persamaan matematika ke teks. Butir soal ini meminta mahasiswa untuk mentranslasi persamaan matematika $\mathrm{F}=\mathrm{qv} \mathrm{X} \mathrm{B}$ ke representasi teks. Sebanyak 79\% mahasiswa melakukan kesalahan dalam menyatakan representasi teks. Kesalahan-kesalahan tersebut antara lain kesalahan dalam memahami simbol persamaan matematika, misalnya menyatakan "v" yang seharusnya adalah simbol dari kecepatan dinyatakan sebagai "beda potensial listrik". Kesalahan berikutnya, representasi teks yang ditulis tidak relevan dengan persamaan matematika, misalnya mengaitkan persamaan matematika $\mathrm{F}=$ qv $\mathrm{X}$ B dengan konsep kutubkutub magnet sebagai berikut, "Gaya magnet adalah gaya yang saling interaksi antara kutub satu dengan kutub lainnya atau kutub utara dan kutub selatan". Diantara kesalahan-kesalahan translasi antar modus representasi yang paling banyak adalah mentraslasi persamaan matematika ke representasi teks. Mahasiswa menyebutkan hubungan antar besaran dalam persamaan matematika tersebut yang secara langsung tidak mencerminkan makna fisis dari konsep gaya Lorentz, seperti yang dinyatakan oleh seorang mahasiswa, "Konsep gaya magnet pada muatan listrik adalah berbanding lurus dengan muatan, kecepatan, kuat medan magnet serta sudut yang dibentuk." Mentranslasi dari modus representasi persamaan matematika ke modus representasi teks, mengharuskan mahasiswa untuk menganalisis terlebih dahulu persamaan yang ada, dalam hal ini hubungan antara parameter yang terdapat dalam persamaan. Berikutnya adalah menentukan apa yang harus dijelaskan dari konsep hukum fisika yang dinyatakan dalam persamaan matematika. Mahasiswa juga harus mengenali simbol yang digunakan dalam persamaan.

Temuan dalam penelitian ini menunjukkan bahwa mahasiswa calon guru fisika tidak terlatih dalam mentranslasi persamaan matematika ke modus representasi teks. Modus representasi teks adalah elemen penting untuk mengkontekstualisasi persamaan matematika sehingga informasi menjadi akrab bagi kehidupan 
siswa. Untuk menjadi guru fisika yang sukses, tidaklah cukup hanya mampu mengidentifikasi kuantitas fisika yang terdapat dalam persamaan dan tahu bagaimana menggunakan persamaan untuk memecahkan masalah fisika. Guru fisika harus mampu membuat penjelasan tentang penalaran matematika dalam fisika sehingga akan meningkatkan kesadaran siswa tentang sifat fisika dan peran matematika. Penjelasan representasi matematika harus dibuat eksplisit ketika memperkenalkannya pada para siswa sehingga mereka dapat memahami dan menginternalisasi fakta bahwa 'rumus' fisika, bertentangan dengan apa yang ditemukan dalam logika atau matematika (De Lazano, 2014)

\section{c. Keterampilan Multirepresentasi}

Keterampilan multirepresentasi dianalisis berdasarkan pada jawaban soal pertama dengan fokus analisis pada kategori kebenaran representasi, kebakuan dan keterpaduan antara saru representasi dengan representasi lainnya. Skor yang dicapai oleh mahasiswa tidak berbeda secara signifikan. Hampir semua mahasiswa (90\%) tampak belum menjelaskan hukum Coulomb secara terpadu dan terkait antara satu representasi dengan representasi lainnya. Temuan Mallet (Mallet, 2007) mendukung hasil pengamatan dalam penelitian ini yang menunjukkan bahwa hubungan antara MR sering tidak dilaksanakan oleh guru selama pembelajaran di kelas. Keadaan tersebut telah disadari oleh peneliti seperti yang dinyatakan Ainsworth (Ainsworth, 1998), bahwa menyediakan representasi di dalam dan di antara MR bukanlah hal yang mudah bagi siswa, mahasiswa calon guru fisika perlu lebih tekun dan berhati-hati dalam mempelajarinya selama masa studi mereka.

\section{d. Kesulitan dalam Merepresentasi Konsep Listrik-Magnet}

Berikut ini adalah penjelasan mahasiswa terkait kesulitan dalam merepresentasi konsep listrik magnet:

1) Kesulitan yang dialami saat membuat representasi teks adalah menyusun kalimat yang baik untuk menjelaskan konsep fisika tertentu agar mudah dipahami pembaca.
2) Kesulitan yang dialami dalam membuat representasi gambar adalah tidak terampil menggambar atau membuat sketsa fenomena fisika dari konsep fisika yang akan direpresentasikan.

3) Kesulitan yang dialami dalam membuat representasi diagram piktorial adalah menentukan parameter apa saja yang akan digambarkan dalam berbagai keadaan pada diagram piktorial.

4) Kesulitan yang dialami dalam membuat tabel adalah membuat tabel sedemikian rupa sehingga pembaca dapat dengan jelas melihat langsung hubungan antara variabel yang tertera dalam tabel dan menentukan variabel-variabel yang harus ditampilkan. 5) Kesulitan yang dialami dalam membuat representasi grafik adalah menentukan variabel-varibel yang harus ditampilkan dan menetapkan variabel bebas dan variabel terikat dari persamaan yang akan direpresentasikan ke dalam modus grafik.

6) Kesulitan yang dialami dalam membuat representasi persamaan matematika adalah mengemas persamaan sehingga menjadi lebih informatif dan mudah dipahami pembaca.

\section{PENUTUP}

Mahasiswa calon guru fisika harus memiliki keterampilan representasi agar dapat membantu belajar siswa atau mengatasi kesulitan siswa dalam memahami konsep-konsep fisika. Untuk memastikan bahwa mahasiswa calaon guru fisika mengembangkan keterampilan representasi yang memadai selama studi sarjana mereka adalah tanggung jawab departemen fisika. Harus ditemukan strategi baru yang memungkinkan untuk mengatasi kurangnya keterampilan representasi yang dapat dipraktikkan dalam memfasilitasi upaya dosen fisika untuk mengubah pengajaran fisika dengan cara yang lebih sesuai dengan kebutuhan mahasiswa saat ini. 


\section{DAFTAR PUSTAKA}

Ainsworth, S. E., Wood, D. J. \& Bibby, P.A. (1998). Analysing the costs and benefits of multirepresentational learning environments. Dalam M. Van Someren, H.P.A. Boshuizen, T. de Jong ve P. Reimann (Eds.), Learning with multiple representations (120-134). Oxford: Elsevier Science

Arey, J \& Linder, C. (2017). Social Semiotics in University Physics Education. Dalam David F. Treagust, D. F, Reinders Duit, R \& Fischer, H.E (Eds), Multiple Representations in Physics Education (95-119). Gewerbestrasse: Springer International Publishing

Berthold, K., Eysink, T.H.S., \& Renkl, A. (2009). Assisting self-explanation prompts are more effective than open prompts when learning with multiple representations

Das, K. (2014). Need of Effective Communication Skills in Teaching Science. International Journal of Educational Research and Technology, 5(September), 40-42.

De Lozano S R and Cardenas M 2002 Some Learning Problems Concerning the Use of Symbolic Language. Physics Science \& Education 11 589-599

Goldin, G.A. (2002). Representation in Mathematical Learning and Problem Solving. Dalam L.D English (Ed). Handbook of International research in Mathematics Education(IRME). New Jersey: Lawrence Erlbaum Associates

Grossman, P. L. (1990). The making of a teacher: Teacher knowledge and teacher education. New York: Teachers College Press

Kohl, P. B \& Finkelstein, N. (2017). Understanding and Promoting Effective Use of Representations in Physics Learning. Dalam David F. Treagust, D. F, Reinders Duit, R \& Fischer, H.E (Eds), Multiple Representations in Physics Education (213-253). Gewerbestrasse: Springer International Publishing

Kress, G., Jewitt, C., Ogborn, J., \& Tsatsarelis, C. (2001). Multimodal teaching and learning:
The rhetorics of the science classroom. London, UK: Continuum

Lemke, J. L. (1999). Multimedia literacy demands of the scientific curriculum. Linguistics and Education, 10(3), 247-271.

Mallet, D. G. (2007). Multiple representations for systems of linear equations via the computer algebra system Maple. International Electronic Journal of Mathematics Education 2(1): pp. 16-32.

Shulman, L. S. (1986). Those who understand: Knowledge growth in teaching. Educational Researcher, 15(2), 4-14

Sinaga, P. (2014). Pengembangan Program Perkuliahan Fisika Sekolah III Untuk Meningkatkan Kompetensi Menulis Materi Ajar Calon Guru Menggunakan Multi Modus Representasi. Disertasi UPI

Spektor-Levy, O., Eylon, B., \& Scherz, Z. (2008). Teaching communication skills in science: Tracing teacher change. Teaching and Teacher Education, 24, 462-477. 